NBER WORKING PAPER SERIES

\title{
DIFFUSION OF COMMON APPLICATION MEMBERSHIP AND ADMISSIONS OUTCOMES AT AMERICAN COLLEGES AND UNIVERSITIES
}

\author{
Albert Yung-Hsu Liu \\ Ronald G. Ehrenberg \\ Jesenka Mrdjenovic \\ Working Paper 13175 \\ http://www.nber.org/papers/w13175
NATIONAL BUREAU OF ECONOMIC RESEARCH
1050 Massachusetts Avenue
Cambridge, MA 02138
June 2007

We thank Rob Killion and Judy Whitman at The Common Application, Renee Gernand at the College Board and Mary Miller at the U.S Department of Education for sharing their data with us, and Genie Birman and Mariya Kupershmidt for research assistance. We are grateful for comments from Bradley Curs, Ofer Malamud, and conference participants at the American Educational Finance Association and Society of Labor Economists meetings. Our research was financed by grants to the Cornell Higher Education Research Institute from the Andrew W. Mellon Foundation, the Atlantic Philanthropies (USA) Inc. and the TIAA-CREF Institute and we thank each of them for their support. The views expressed herein are those of the author(s) and do not necessarily reflect the views of the National Bureau of Economic Research.

(C) 2007 by Albert Yung-Hsu Liu, Ronald G. Ehrenberg, and Jesenka Mrdjenovic. All rights reserved. Short sections of text, not to exceed two paragraphs, may be quoted without explicit permission provided that full credit, including $(\mathrm{C}$ notice, is given to the source. 
Diffusion of Common Application Membership and Admissions Outcomes at American Colleges and Universities

Albert Yung-Hsu Liu, Ronald G. Ehrenberg, and Jesenka Mrdjenovic

NBER Working Paper No. 13175

June 2007

JEL No. I21,L11,L14

\begin{abstract}
We study the adoption of Common Application membership by private four-year postsecondary institutions and its role in explaining the growth in undergraduate applications. Using data from the College Board's Annual Survey of Colleges, our estimation of proportional hazard models suggest that institutions respond to the net benefit of adoption. We estimate that membership increases applications by 5.7 to 7.0 percent and decreases yield rates by 2.8 to 3.9 percent. Acceptance rates decrease for members when their local networks are large. Membership is also associated with a decline in SAT scores and an increase in the percentage of students of color. Finally, falsification tests indicate that membership effects occur as a one-time adoption shock that persists thereafter.

\author{
Albert Yung-Hsu Liu \\ Cornell University \\ Department of Economics \\ Uris Hall \\ Ithaca, NY 14853-7601 \\ ayl23@cornell.edu
}

Ronald G. Ehrenberg

Cornell Higher Education Research Institute

385 Ives Hall East

Ithaca, NY 14853-3901

and NBER

rge2@cornell.edu

\author{
Jesenka Mrdjenovic \\ Cornell Higher Education Research Institute \\ 385 Ives Hall East \\ Ithaca, NY 14853-3901 \\ jm398@cornell.edu
}




\section{Introduction}

Between 1975 and 2005, the share of first year students that applied to four or more institutions the previous year grew from 12.0 percent to 38.6 percent (Pryor, Hurtado, Saenz, Santos, and Korn 2007). Our own estimates over the same period suggest that the mean number of applications received by private four-year institutions increased from 1,282 to 3,129 . One potential explanation for the growth in undergraduate applications is that the college wage premium has increased since the 1970s, particularly for graduates of highly selective institutions (Murphy and Welch 1993; Brewer, Eide, and Ehrenberg, 1999). Increasing market returns to postsecondary education may induce risk-averse prospective students to apply to more colleges and universities.

An alternative explanation is that the market structure of postsecondary education has transformed from a collection of local markets into a nationally competitive marketplace (Hoxby 1997). This implies that colleges and universities have increasing incentives to increase institutional prestige. Perhaps the most widely followed measure of prestige comes from the U.S. News and World Report's (USNWR) America's Best Colleges which rewards higher mean SAT scores, lower acceptance rates, and until recently, higher yield rates. Annual changes in rankings have substantial consequences including the quality of students that enroll the following year (Monks and Ehrenberg 1999). There is even some evidence that college and universities manipulate admissions processes to boost USNWR rankings in otherwise counterproductive ways (Avery, Glickman, Hoxby, and Metrick 2004).

Our focus in this paper is on an institutional choice that enhances USNWR prestige by generating advantageous changes in undergraduate admissions outcomes. Each year since 1975, 
the Common Application (CAPP) non-profit organization issues a standardized application form that prospective students may submit to institutions that pay the membership fee. We present a model where membership decreases the opportunity time cost of completing an application for prospective students and increases the number of applications received by the institution. Membership also exhibits network externalities because it reduces the application price at all other member institutions causing membership effects to grow with network size.

To empirically test our model, we analyze the diffusion of CAPP adoption among private, postsecondary institutions between 1975 and 2005 using the College Board's Annual Survey of Colleges. Estimates from proportional hazards models stratified by Carnegie classification suggest the presence of network externalities: the probability of adoption conditional on being at risk increases with the membership share in the state, division, or region. We also find that higher membership fees decrease the conditional probability of adoption which is surprising given that they are small relative to annual institutional revenues.

We then directly estimate the effects of CAPP membership on a set of undergraduate admissions outcomes. To our knowledge, our paper is the first to emphasize the effects of application prices; the closest studies estimate the effects of list and net tuition on application behavior (Savoca 1990; Curs and Singell 2002). OLS and two-stage least squares models show that membership increases applications, admittances, and enrollment and decreases yield rates. Interaction terms reveal differential impacts such as the presence of network externalities for applications and acceptance rates. We also conduct a series of falsification tests that vary the timing of adoption and show that membership effects occur as a one-time shock at adoption. These dynamics and the presence of network externalities suggest that competition-driven CAPP membership diffusion contributes to the growth in applications. 
CAPP membership may also affect the characteristics of applicants, admitted prospective students, and enrolled students. In fact, the mission statement of the CAPP non-profit organization includes a commitment to promote equity and access (The Common Application, 2007). Unfortunately, data restrictions force us to focus on the characteristics of enrolled students rather than on applicants or admitted prospective students. We find that CAPP membership results in a small decrease in mean SAT scores and large increase the percent students of color. Membership thus not only affects the number of people at each stage of the admissions process but the characteristics of those that ultimately enroll as well.

\section{Application Prices and the College Admissions Process}

Recent studies of postsecondary education emphasize enrollment responses to the tuition paid by prospective students (Leslie and Brinkman 1988; Dynarksi 2002; Van Der Klaauw 2002; Avery and Hoxby 2004). Less attention is paid to the application stage, although there is some evidence that the probability of applying to an institution decreases with list or expected net tuition (Savoca 1990; Curs and Singell 2002). Our focus in this paper is on the effects of application price changes on applications and admissions outcomes more broadly. Expanding applicant pools is of increasing importance because to boost prestige, many institutions seek lower acceptance rates and offer preferentially packaged financial aid to enroll the optimal set of applicants.

\subsection{Student and Institution Behavior with the CAPP}

Our model of college admissions begins with the decision to submit applications by prospective students and builds on Manski and Wise (1983). Students choose whether to apply to an institution by comparing the utilities with and without enrollment at the institution. We 
assume that the utility of enrollment increases with institutional prestige based on institutional characteristics the previous year. This is consistent with prospective students assessing quality based current USNWR rankings. This also assumes that prospective students do not anticipate any effects of CAPP membership on institutional quality.

The utility of enrollment decreases with the application price which consists of the opportunity time cost of completing an application form and the monetary fee assessed by the receiving institution. ${ }^{1}$ Using the CAPP application form when it is accepted decreases the opportunity time cost but has no effect on the monetary fee. The reduction in overall price generates additional applications. This occurs both on the intensive margin, where existing applicants increase the number of applications submitted, and on the extensive margin, where new prospective students start applying for college because the overall cost is lower.

A salient feature of the membership is that it exhibits network externalities. Network externalities exist when the benefit of a good changes with the number of other agents consuming the same type of good (Liebowitz and Margolis 2004). In this context, the time cost savings to a prospective student occurs at every institution that accepts the standardized form. Membership effects are greater when the network size is large.

How do institutions respond to the increase in applications? Colleges and universities that accept the CAPP application form will receive additional applications from qualified prospective students and prospective students who are likely to enroll if granted admission (such as students applying to "reach" schools). Institutions that focus on selectivity and yield rates as components of prestige increase admittances because there are newly desirable prospective students in the applicant pool. This implies that CAPP membership will have an ambiguous

\footnotetext{
${ }^{1}$ Recently, some institutions issue fee waivers for online applicants.
} 
effect on acceptance rates (admittances / applications). Lastly, we assume that institutions have constant enrollment targets in the short-run to generate sufficient tuition revenue but not exceed capacity constraints. Thus, membership unambiguously decreases yield rates (enrollment / admittances).

\subsection{The Diffusion of CAPP}

Our model assumes that the membership benefits for colleges and universities are the additional applications, and possibly lower acceptance rates, that are rewarded with USNWR prestige. The costs are the CAPP membership fees and the intended and unintended consequences on student body characteristics. While we are able to measure some aspects of student characteristics such as SAT scores, percent students of color, and percent low-income students, we undoubtedly ignore others that may foster enthusiasm or resistance at some institutions. $^{2}$

We employ the diffusion of innovations model to analyze the institutional adoption of CAPP membership. Firms adopt an innovation when the net benefits of doing so are positive. For example, net benefits may increase with firm size when the profit of successful adoption exhibits economies of scale (Davies 1979 as described by Baptista 1999). Larger firms may also be better able to bear the risk of unsuccessful innovations.

In a representative reduced-form approach, Rose and Joskow (1990) show that larger firms are indeed more likely to adopt coal-fired steam-electric generating technology in the electric utility industry. Moreover, the probability of adoption conditional on being at risk increases with the cost of pre-innovation technology. Adoption may also be more likely when

2 The University of Chicago recently debated CAPP membership where opponents claimed that membership would change the character of the institution. This institution has called its undergraduate application the Uncommon Application since 1998. 
the net benefit of the innovation exhibits network externalities. For example, controlling for other economies of scale, banks with more local branches have higher probabilities of ATM (automatic teller machines) adoption conditional on being at risk (Saloner and Shepard 1995). This approach may also include the strategic components of adoption. The conditional probability of ATM adoption by banks increases when competitors adopt the previous period, a phenomenon Hannan and McDowell (1987) describe as rival precedence.

However, external validity may be a concern when studying the diffusion of industryspecific innovations: it is not obvious that the diffusion of coal-fired steam electric technology or ATMs operate like innovations in postsecondary education. We are only aware of one study, Getz, Siegfried, and Anderson (1997), that applies this approach to postsecondary education. For thirty technologies including library, computing, and classroom innovations, the probability of adoption conditional on being at risk depends on public or private control, financial resources, and institution type (liberal arts, research, or university).

\section{Data and Empirical Methods}

The CAPP non-profit organization generously provided us with the complete adoption history of all institutional members since its inception in 1975. Our sample, which includes members and non-members, consists of four-year private colleges and universities in the College Board's Annual Survey of Colleges that meet minimal data requirements. ${ }^{3}$ We exclude public institutions because they comprise only 4 percent of members in 2005 with the first adoption

\footnotetext{
${ }^{3}$ The sample consists of institutions that report in 1974 and 2005, respond for at least 20 years, and contain at least 10 years of data on applications. Our empirical findings are robust to 5-year variations in the latter two requirements. We drop other-type Carnegie classification institutions and those missing mean SAT scores throughout the panel. There is no College Board data in $1975,1977,1980,1981$, or 1983 . We impute missing values for interior points with linear interpolation and exterior points with the outermost non-missing value.
} 
occurring in 2001. The final sample consists of 638 institutions in each year from 1975 to 2005 , of which 250 adopt in some year. Each observation consists of institutional data for first year undergraduate students in year $t$ where their applications and applications submitted by those denied admission or did not enroll were actually submitted in year $t-1$.

[Figure 1. Applications by CAPP Status]

Figure 1 presents the mean number of applications per year for institutions with CAPP membership in some year and those that never adopt. Institutions that never adopt experienced a 130 percent growth in average applications over the entire period from 836 applications in 1974 to 1,926 applications in 2005 . In contrast, average applications at institutions with membership experience grew 162 percent from 1,900 in 1974 to 4,996 in 2005 . While this suggests differential trends in applications by membership, selection may be an issue because mean applications for these groups were different before the CAPP non-profit organization was created.

[Table 1. Sample Means in 1974]

CAPP and non-CAPP institutions vary by other characteristics as well. Table 1 presents mean institutional characteristics in 1974, one year before the onset of risk; we reject the hypotheses that the means for the two groups are equal for each admissions outcome and institutional characteristic except percent Masters and the location dummy variables. CAPP institutions have greater applications, admittances, and enrollment. They also have lower 
acceptance and yield rates and higher mean SAT scores. ${ }^{4}$ CAPP institutions are more likely to be $\mathrm{PhD}$ institutions as designated by their Carnegie classification, where each institution is a Doctoral (PhD), Masters (MA), or Bachelors (BA) institution. We also collect application fee and list tuition data (in 2005 dollars) for 1985-2005 and find that CAPP institutions have greater application fees and list tuition in $1985 .^{5}$

We describe the empirical diffusion strategy next because the resulting estimates will inform the subsequent program evaluation section of the paper. Our analysis of adoption centers on the hazard rate $h$ in Equation 1. The hazard rate of institution $i$ in state $s$ in period $t$ is the instantaneous probability of adopting CAPP membership conditional on not having adopted by period $t$.

$$
h\left(t \mid \text { memberfee }_{\text {ist }}, \text { pctcapp }_{\text {ist }}, \mathbf{X}_{\text {ist }}\right)=\frac{f\left(t \mid \text { memberfee }_{\text {ist }}, \text { pctcapp }_{\text {ist }}, \mathbf{X}_{\text {ist }}\right)}{1-F\left(t \mid \text { memberfee }_{\text {ist }}, \text { pctcapp }_{\text {ist }}, \mathbf{X}_{\text {ist }}\right)}
$$

The hazard rate depends on the CAPP membership fee. The CAPP non-profit organization set constant price schedules for 1980-1982, 1983-1992, 1993-1999, 2000-2001, and 2002-2005. Institutions are sorted into groups based on the previous year's total number of applications, and all institutions within a group are charged the same price. For example, the price schedule in 1993-1994 charged institutions with 0-999 applications \$550, 1,000-1,499 applications $\$ 600,1,500-1,999$ applications $\$ 650$, and 2,000-2,499 applications $\$ 700,2,500$ -

${ }^{4}$ Mean SAT scores are re-centered and calculated as the average of the $25^{\text {th }}$ and $75^{\text {th }}$ percentile score at the institution. When missing, we convert ACT scores into re-centered SAT scores.

${ }^{5}$ We impute missing tuition in the Annual Survey of Colleges with values from the Integrated Postsecondary Education Data System (IPEDS). In cases where IPEDS reports tuition and fees together, we subtract estimated fees based on within-institution averages of the fee to total cost ratio over the entire period. 
2,999 applications $\$ 750$, and 3,000 or more applications $\$ 800 .^{6}$ We convert the price of membership into the fee per first year enrolled student in 2005 dollars $\left(\right.$ memberfee $\left._{i s t}\right)$. The mean price across all years is $\$ 3.36$ per first year student.

The second variable of interest is our measure of network size, the CAPP membership rate in the network (excluding institution $i$ ) in state $s$ in period $t\left(\right.$ pctcapp $_{\text {ist }}$ ). Ideally, we would construct annual revealed-preference networks of the type described in Avery, Glickman, Hoxby, and Metrick (2004), but such data were not available to us. Instead, we define network competitors as other private institutions the state, although we experiment with specifications using Census divisions and regions instead. Lastly, the hazard rate depends on a vector of institutional characteristics $\mathbf{X}_{\text {ist }}$ which includes mean SAT score (sat ${ }_{i s t}$ ), mean SAT score squared (satsq $\left.q_{i s t}\right)$, percent on-campus students (pctcampus $\left.{ }_{i s t}\right)$, percent in-state students (pctinstate $_{i s t}$ ), religious affiliation (religion $\left.{ }_{\text {ist }}\right)$, urban location $\left(\right.$ urban $\left._{i s t}\right)$, and rural location $\left(\operatorname{rural}_{i s t}\right)$.

[Figure 2. Smoothed Hazard Estimates by Carnegie Classification]

We present two non-parametric estimates of the hazard rate in Figure 2 and Figure 3 to guide our analysis. Each line is a kernel density estimator of the hazard rate for institutions disaggregated by Carnegie classification or by SAT group with bandwidths that minimize mean integrated squared error. The SAT groups are 0 to 33 (low), 34 to 66 (middle), and 67 to 100 (high) percentiles of the mean SAT score. To fix groups, we categorize institutions based on their 1974 values.

${ }^{6}$ Members that use the CAPP application form exclusively were charged $\$ 100$ between 1980 1982 and 1983-1992. More recently, institutions are charged an additional membership fee for each online application submitted and a surcharge for online supplements. Prices for 1975 to 1979 are unavailable and are imputed with 1980 prices. 
[Figure 3. Smoothed Hazard Estimates by SAT Group]

The hazard rates have three inflection points with local maxima just after the inception of the CAPP non-profit organization and again in the mid-1990s. Wilcoxon tests reject the hypotheses that the hazard rates by Carnegie classification or by SAT group are equal. $\mathrm{PhD}$ and most selective institutions consistently have the greatest conditional probabilities of adoption. The shapes of the hazard rates, particularly those of MA and BA institutions that cross between periods 12 and 13, do not conform to any of the well-known functions (i.e. exponential or Weibull). This suggests that a fully parametric specification of these forms would be misspecified. Thus, we estimate semi-parametric Cox proportional hazards model stratified by Carnegie classification as presented in Equation 2. Each Carnegie classification has its own baseline hazard rate, but we assume that the coefficients of the explanatory variables are the same across groups. Our discussion above leads us to expect that $\beta_{1}<0$ and $\beta_{2}>0$.

$$
\begin{aligned}
h\left(t \mid \text { memberfee }_{\text {ist }}, \text { pctcapp }_{\text {ist }}, \mathbf{X}_{\text {ist }}\right) & =h_{0}^{j}(t) \exp \left(\beta_{1} \text { memberfee }_{\text {ist }}+\beta_{2} \text { pctcapp }_{\text {ist }}+\mathbf{X}_{\text {ist }} \gamma\right) \\
j & \in\{\mathrm{PhD}, \mathrm{MA}, \mathrm{BA}\}
\end{aligned}
$$

The second part of our analysis estimates the effects of CAPP membership on a set of undergraduate admissions outcomes: applications, admittances, enrollments, acceptance rates, yield rates, mean SAT scores, percent students of color, and percent low-income students. We calculate admissions outcomes for each first year cohort (combining full-time and part-time) except for the percent low-income students which is not available. Instead, we use the percent of all undergraduate students (both full-time and part-time) that receive Pell Grants as a measure of percent low-income students. 


$$
\begin{aligned}
& \log \_ \text {admis }_{i s t}^{k}=\theta_{1}^{k} \log \_ \text {applyfee } \text { ist-1 }_{1}+\theta_{2}^{k} \log \_ \text {tuition }_{\text {ist- } 1}+\theta_{3}^{k} \text { capp }_{\text {ist }-1}+ \\
& \theta_{4}^{k} \text { pctcapp }_{i s t-1}+\mathbf{X}_{i s t-1} \boldsymbol{\delta}^{k}+\sigma_{c}^{k}+\sigma_{i}^{k}+\sigma_{s}^{k}+\sigma_{t}^{k}+\varepsilon_{i s t}^{k}
\end{aligned}
$$

We employ a standard program evaluation approach in Equation 3 where we regress log admissions outcome $k$ for institution $i$ in state $s$ in year $t$ on a set of institutional characteristics.

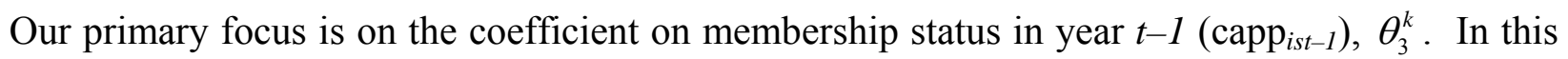
section, we include Carnegie classification dummy variables as an institutional characteristic $\left(\sigma_{c}^{k}\right)$. We also include the $\log$ of list tuition $\left(\log _{-}\right.$tuition $\left.{ }_{i s t-1}\right)$ in $t-1$ because previous studies show it to be associated with applications (Savoca 1990; Curs and Singell 2002), yield rates (Avery and Hoxby 2004), and enrollment (Allen and Shen 1999). We do not correct for the effects of grants, loans, or other financial aid on tuition in this paper. A novel feature of our analysis is that we include the application fee (log_applyfee $\left.{ }_{i s t-1}\right)$ in $t-1$ in 2005 dollars which to our knowledge has yet to be used in the literature. ${ }^{7}$ Our prior is that $\theta_{1}^{k}<0$ for applications. Because application fees are unavailable in the early years of the panel, we restrict the evaluation sample to 1985 to 2005 .

The remaining independent variables are membership status and institutional characteristics in $t-1$ with institution, state, and year fixed-effects. Institution fixed effects control for unobserved time-constant characteristics such as the character of the student body, the quality of athletic programs, and neighborhood amenities, and the state and year fixed effects control for demographic and market structure changes. We also restrict the sample to institutions that report admissions data in both $t$ and $t-1$ to match those used our falsification tests described in the next section.

\footnotetext{
${ }^{7}$ We also include a dummy variable for no application fee.
} 
Because membership may be endogenous, we estimate two-stage least squares models using the insights generated from our diffusion model estimates. We approximate CAPP membership status in $t-1$ with a linear probability model and use membership and membership rate in the state in $t-2$ and $t-3$. With this approach, we assume that these characteristics have no effect on admissions outcomes other than through their effects on membership in $t-1$.

\section{Empirical Results}

\subsection{Diffusion of CAPP Adoption}

We present our estimates for the baseline proportional hazards model in Table 2. We use time-invariant independent variables $(t=1974)$ to fix groups as they were before the CAPP program. Only membership fee and network size are time-varying independent variables. The left panel uses the full sample of institutions where the baseline hazard is allowed to vary by Carnegie classification. The first column excludes institutional controls $\mathbf{X}_{i s t}$ and shows that the conditional probability of adoption decreases by 25 percent for a one dollar increase in the membership fee per enrolled student. ${ }^{8}$ We find suggestive evidence of network externalities where a one percentage point increase in the membership rate in the state raises the hazard rate by 2.2 percent. Because the average state in the sample has 13.6 private institutions, this implies that an additional member in the network raises the hazard rate by 16.2 percent.

Column 2 adds the set of institutional controls. In general, institutions with higher SAT scores are more likely to adopt CAPP membership conditional on being at risk with a peak at 1320 SAT points $\left(95^{\text {th }}\right.$ percentile). Institutions with higher rates of on-campus residence are also more likely to adopt, perhaps because they have greater financial costs of falling below

\footnotetext{
${ }^{8}$ Marginal effects for relative probabilities are equal to exp(coefficient estimate).
} 
enrollment targets. Institutions with a religious affiliation are less likely to adopt membership because they are typically interested in a specific subset of potential applicants.

\section{[Table 2. Proportional Hazards Model, Coefficient Estimates]}

We disaggregate the sample by Carnegie classification and SAT group in the middle and right panels respectively. This approach relaxes the assumption that the coefficients between groups are equal. $\mathrm{PhD}$ institutions are the only group that does not respond to the price of membership, although this may be due to small sample size. Nevertheless, these institutions typically have the greatest financial resources at their disposal. The conditional probability of adoption increases with network size only for MA and middle SAT institutions which suggests that they are the ones that benefit most from the network externalities that accompany CAPP membership.

We also estimate several variants of these models which are not formally presented here but are available from the authors upon request. First, the construction of the membership fee opens the possibility that the negative effects presented in Table 2 are due to the number of applications rather than the cost of the innovation. When we control for institution size with log applications or log enrollment, the negative effect of membership fee persists. Second, we experiment with defining networks as competitors in the Census division or region because prospective students are increasingly applying to colleges and universities outside their home states (Hoxby 19997). We find evidence of network externalities at these broader geographic levels that are similar to those using state-based networks. ${ }^{9}$ We also estimate models that use the number of members in the network or whether a member in the network adopted the previous

\footnotetext{
${ }^{9}$ See Appendix Table 1.
} 
year but do not find any evidence that they predict adoption. We take this as evidence against the rival precedence behavior found in previous empirical adoption studies (Hannan and McDowell 1987).

Our results are also robust to using time-varying measures of all independent variables. Because the non-parametric estimates in Figure 2 show that the hazard rates for MA and BA institutions cross, we verify that the results are not an artifact of our missing data imputation procedure that allocates Carnegie classification in 1988 to 1975-1987. Our results are robust to artificially left-censoring the data in 1988 .

The sample also includes 25 institutions that join and then drop CAPP membership. We estimate a probit model for the probability of dropping membership for the set of institutions that ever adopt. Using the same set of independent variables described above, we find that institutions with smaller networks that had become CAPP members are more likely to eventually drop their membership.

\subsection{Admissions Outcomes}

We now turn to estimating the effects of CAPP membership on admissions outcomes. We present the results from our OLS estimates in Table 3 where each column is a separate regression for undergraduate admissions outcome $k$. Our main finding is that CAPP membership in $t-1$ is associated with a 5.7 percent increase in applications (reported in $t$ but occurring in $t-1$ ). This is the first evidence that a reduction in the application price generates an increase in the number of applications. We also find that CAPP membership is associated with a 5.2 percent change in admittances and a 3.7 percent change in enrollment. When we estimate the effects on the acceptance rate directly, we find no evidence of any membership effect. In contrast, membership is associated with a -2.8 percent change in yield rate. Our interpretation is that 
institutional membership expands the applicant pool but draws in some applicants who are less likely to enroll if admitted.

[Table 3. OLS Membership Effects on Log Admissions Outcomes]

We also control for log application fee and log tuition in $t-1$. An increase in the monetary application fee reduces applications with an own-price elasticity of -0.062 . An interesting result is that charging a higher application fee increases yield rates, and our interpretation is that higher application fees limit the applicant pool to more "serious" applicants. This result is consistent with the negative effect of membership on yield rates. List tuition is weakly negatively associated with enrollment, although we do not emphasize the results here due to usual omitted ability problems (Dynarski 2002). We also find that the yield rate decreases with the listed tuition which is consistent with Parker and Summers (1993).

Institutional membership in CAPP may also generate changes in the characteristics of the students that ultimately enroll at the institution. CAPP membership in $t-1$ is associated with a 1.1 percent decrease in mean SAT scores. We also find that membership is associated with a 15.4 percent change in the percent students of color and a 2.4 percent change in the percent Pell Grant recipients. These results suggest that CAPP membership enables institutions to enroll a more diverse study body by enrolling more students of color and those from low-income households. This is consistent with previous evidence that low-income applicants benefit most from increased information on the college application process (Avery and Kane 2004), but a more rigorous test of this hypothesis should be conducted with applicant micro-level data.

[Table 4. OLS Membership Effects on Log Admissions Outcomes, Interaction Terms] 
We test whether the effects of membership on admissions outcomes varies by two key institutional characteristics in Table 4. The top panel presents estimates for OLS specifications that include the interaction between CAPP membership in $t-1$ and network size in $t-1$. We find evidence of network externalities in that a one percentage point increase in the network size is associated with a 0.1 percent increase in applications for CAPP members. We find similar evidence of network externalities in that the acceptance rate falls with the network size in the state.

The bottom panel presents estimates that include the interaction between membership and mean SAT score. Membership increases applications more at lower SAT institutions, perhaps because applicants apply to more "safety" schools once the cost of doing so decreases. These are also the institutions that may have trouble attracting students. Admittances increase more at lower SAT member institutions which suggests that they expect the newly admitted students to be less likely to matriculate or are further from their capacity constraints. Member institutions with higher SAT scores experience a decrease in the acceptance rate which provides evidence that it is the most selective institutions that benefit from membership in terms of USNWR rankings. In addition, the yield rate declines less in absolute value at higher SAT score colleges and universities. As expected, applicants that get into the most prestigious schools enroll there if admitted. These results confirm the positive effects of network size and mean SAT score on the hazard rate of adoption.

[Table 5. 2SLS Membership Effects on Log Admissions Outcomes]

The diffusion estimates presented in the previous subsection indicate that CAPP membership is endogenous. To control for this endogeneity, Table 5 presents the IV estimates 
using membership status and membership rate in the state $t-2$ and $t-3$ instruments for membership in $t-1$. This procedure has little effect on the CAPP membership coefficients. Membership increases applications by 6.0 percent, admittances by 5.7 percent, and enrollment by 3.5 percent. There is also -3.7 percent change in yield rates. Lastly, we continue to find that membership decreases SAT scores and increases the percent students of color but that it no longer has any effect on the percent of Pell Grant recipients.

[Table 6. First Difference Falsification Tests]

As a robustness check, we estimate a series of falsification tests based on the first difference equation presented in Equation 4. Differencing current and one-year lagged CAPP membership $(t-1+l$ and $t-2+l)$ implies that we are estimating the effect of adoption and not membership on admissions outcome $k$. This approach will show whether membership effects are consistent with the timing of adoption and whether the effects persist over time. A membership effect associated with adoption that has not yet taken place would suggest that the program evaluation estimates are misspecified.

$$
\begin{aligned}
& \Delta \log \text { admis }_{\text {ist }}^{\mathrm{k}}=\phi_{1}^{k} \Delta \log \text { applyfee }_{\text {ist-1 }}+\Delta \phi_{2}^{k} \log \_ \text {tuition }_{\text {ist-1 }}+\phi_{3}^{k} \Delta \text { capp }_{\text {ist }-1+l}+ \\
& \phi_{4}^{k} \text { pctcapp }_{\text {ist- } 1}+\mathbf{X}_{\text {ist- } 1} \boldsymbol{\tau}^{\mathbf{k}}+\Delta \sigma_{t}+\mu_{\text {ist }}^{k}, \\
& l \in\{-2,-1,0,1,2\}
\end{aligned}
$$

The estimates in Table 6 indicate that the effects of adoption occur at adoption. Adoption in $t-1$ increases applications by 7.0 percent and admittances by 4.3 percent in $t$. There is no effect on enrollment, but adoption last year decreases both acceptance rates and yield rates. The lack of systematic significant effects for two or three year lagged adoption suggests that the dynamics of membership effects are a one-time persistent jump at adoption. The non-significant 
coefficients in the future suggest that there is no Ashenfelter-dip phenomenon taking place here (Ashenfelter 1978).

\section{Concluding Remarks}

We find evidence that Common Application membership is a strategic decision by private colleges and universities. CAPP membership increases applications by 5.7 to 7 percent and admittances by 4.3 to 5.9 percent. We find evidence of network externalities in that the effects on applications and acceptance rates change with our measure of network size. These results are consistent with the diffusion estimates that show the net benefit as measured by these characteristics increase the hazard rate of adoption. Our analysis of CAPP membership supports the hypothesis that the postsecondary education market has structurally evolved into a more competitive marketplace.

We also find that CAPP membership affects the composition of students that ultimately enroll. In both OLS and two-stage least squares specifications, membership is associated with a small decrease in SAT scores and a sizeable increase in the percent students of color. We also find some evidence that membership is associated with a small increase in the percent of Pell Grant recipients at the institution. These results suggest that the Common Application non-profit organization has had some success in meeting its goals of increased access and equity.

There are at least two limitations to our analysis. First, we do not address the fact that many institutional members require applicants to complete supplemental forms. These forms provide institutions with idiosyncratic information unavailable in the standardized application form. In fact, unpublished data from the College Board from 2000 to 2004 shows that over half of all institutions that accept the CAPP application form require applicants to complete at least one supplemental form. A second limitation is that many institutions accept the CAPP 
application form without actually paying the membership fee. However, the prevalence of this activity is likely to decline over time because applicants are increasingly applying online - online applications are submitted directly to the CAPP non-profit organization rather than the institution. Both of these limitations suggest that our estimates are lower bounds on the true effects of CAPP membership. 


\section{References}

Ashenfelter, Orley. 1978. "Estimating the Effect of Training Programs on Earnings." The Review of Economics and Statistics 60(1):47-57.

Avery, Christopher, Mark Glickman, Caroline Hoxby, and Andrew Metrick. 2004. "A Revealed Preference Ranking of U.S. Colleges and Universities.” NBER Working Paper No. 10803.

Avery, Christopher and Caroline Hoxby. 2004. "Do and Should Financial Aid Packages Affect Students' College Choices?" In College Choices: The Economics of Where to Go, When to Go and How to Pay for It. Edited by Caroline Hoxby. The University of Chicago Press: Chicago, IL.

Avery, Christopher and Thomas J. Kane. 2004. "Student Perceptions of College Opportunities: The Boston COACH Program." In College Choices: The Economics of Where to Go, When to Go and How to Pay for It. Edited by Caroline Hoxby. The University of Chicago Press: Chicago, IL.

Allen, Robert F. and Jianshou Shen. 1999. "Some New Evidence of the Character of Competition among Higher Education Institutions." Economics of Education Review 18(4): 465470 .

Baptista, Rui. 1999. "The Diffusion of Process Innovations: A Selective Review." International Journal of the Economics of Business 6(1):107-129.

Brewer, Dominic J., Eric R. Eide, and Ronald G. Ehrenberg. 1999. "Does It Pay to Attend an Elite Private College? Cross-Cohort Evidence on the Effects of College Type on Earnings." Journal of Human Resources 34(1):104-123.

Curs, Bradley and Larry D. Singell Jr. 2002. "An Analysis of the Application and Enrollment Processes for In-state and Out-state Students at a Large Public University." Economics of Education Review 21(2): 111-124.

Davies, Stephen. 1979. The Diffusion of Process Innovations. Cambridge: Cambridge University Press.

Dynarski, Susan. 2002. “The Behavioral and Distributional Implications of Aid for College." American Economic Review 92(2):279-285.

Getz, Malcolm, John J. Siegfried, and Kathryn H. Anderson. 1997. "Adoption of Innovations in Higher Education." Quarterly Review of Economics and Finance 37(3):605-631.

Hannan, Timothy H. and John M. McDowell. 1987. "Rival Precedence and the Dynamics of Technology Adoption: an Empirical Analysis." Econometrica 54(214):155-171. 
Hoxby, Caroline M. 1997. "How the Changing Market Structure of U.S. Higher Education Explains College Tuition.” NBER Working Paper No. 6323.

Leslie, Larry L. and Paul T. Brinkman. 1988. The Economic Value of Higher Education. New York City, NY: Macmillan Publishing Company.

Liebowitz, S. J. and Stephen E. Margolis. 2004. "Network Externalities (Effects)." The New Palgrave Dictionary of Economics and the Law. Palgrave Macmillan.

Manski, Charles F. and David A. Wise. 1983. College Choice in America. Cambridge, MA: Harvard University Press.

Monks, James and Ronald G. Ehrenberg. 1999. “U.S. News and World Report's College Rankings: Why Do They Matter?” Change 31(6): 42-51.

Murphy, Kevin M. and Finis Welch. 1993. "Inequality and Relative Wages." American Economic Review 83(2): 104-109.

Parker, Jeffrey and Jeffery Summers. 1993. "Tuition and Enrollment Yield at Selective Liberal Arts Colleges." Economics of Education Review 12(4): 311-324.

Pryor, John, Sylvia Hurtado, Victor B. Saenz, Jose L. Santos, and William S. Korn. 2007. The American Freshman: Forty-Year Trends, 1966-2006. Los Angeles, CA: Higher Education Research Institute, University of California Los Angeles.

Rose, Nancy L. and Paul L. Joskow. 1990. "The Diffusion of New Technologies: Evidence From the Electric Utility Industry." Rand Journal of Economics 21(3):354-373.

Saloner, Garth and Andrea Shepard. 1995. "Adoption of Technologies with Network Effects: An Empirical Examination of the Adoption of Automated Teller Machines." Rand Journal of Economics 26(3):479-501.

Savoca, Elizabeth. 1990. "Another Look at the Demand for Higher Education: Measuring the Price Sensitivity of the Decision to Apply to College." Economics of Education Review 9(2): 123-134.

The Common Application. 2007. Mission. Available at http://www.commonapp.org/index 1.cfm?fuseaction=missionStatement.

Van der Klaauw, Wilbert. 2002. "Estimating the Effect of Financial Aid Offers on College Enrollment: A Regression-Discontinuity Approach." International Economic Review 43(4):1249-1287. 
Figure 1. Applications by CAPP Status

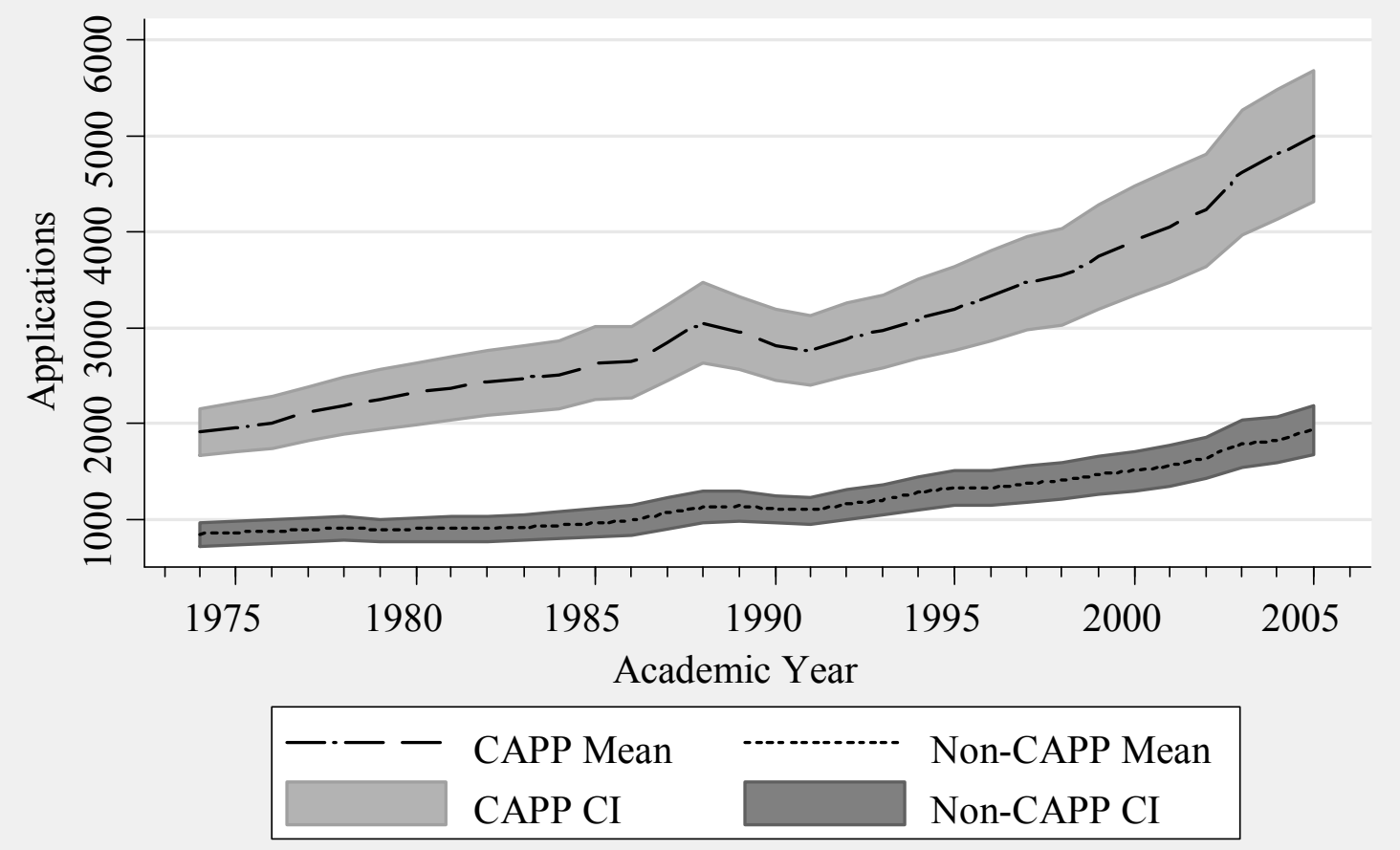

Source: Authors' calculations using CAPP and ASC data. 
$\underline{\text { Table 1. Sample Means in } 1974}$

\begin{tabular}{lrr}
\hline \hline & \multicolumn{1}{c}{$(1)$} & \multicolumn{1}{c}{$(2)$} \\
\hline Admissions Characteristics & Non-CAPP & \multicolumn{1}{c}{ CAPP } \\
\cline { 2 - 3 } apply & 835.598 & 1900.144 \\
admit & 617.263 & 1182.688 \\
enroll & 364.979 & 560.276 \\
acceptrate & .842 & .719 \\
yieldrate & .640 & .502 \\
sat & 10.002 & 11.692 \\
pctsoc & .110 & .078 \\
pctpell & .303 & .192 \\
& & \\
Institutional Controls & Non-CAPP & CAPP \\
\cline { 2 - 3 } PhD & .054 & .172 \\
MA & .340 & .304 \\
BA & .606 & .524 \\
pctcampus & .670 & .797 \\
pctinstate & .616 & .479 \\
religion & .822 & .492 \\
urban & .232 & .252 \\
suburb & .487 & .504 \\
rural & .281 & .244 \\
applyfee (in 1985) & 28.957 & 43.097 \\
tuition (in 1985) & 8.926 & 13.456 \\
N & & \\
\hline Notes: sat in 100s and tuition in 1000s. applyfee and \\
tuition are in 2005 dollars. & & \\
\hline & & \\
\hline
\end{tabular}


Figure 2. Smoothed Hazard Estimates by Carnegie Classification

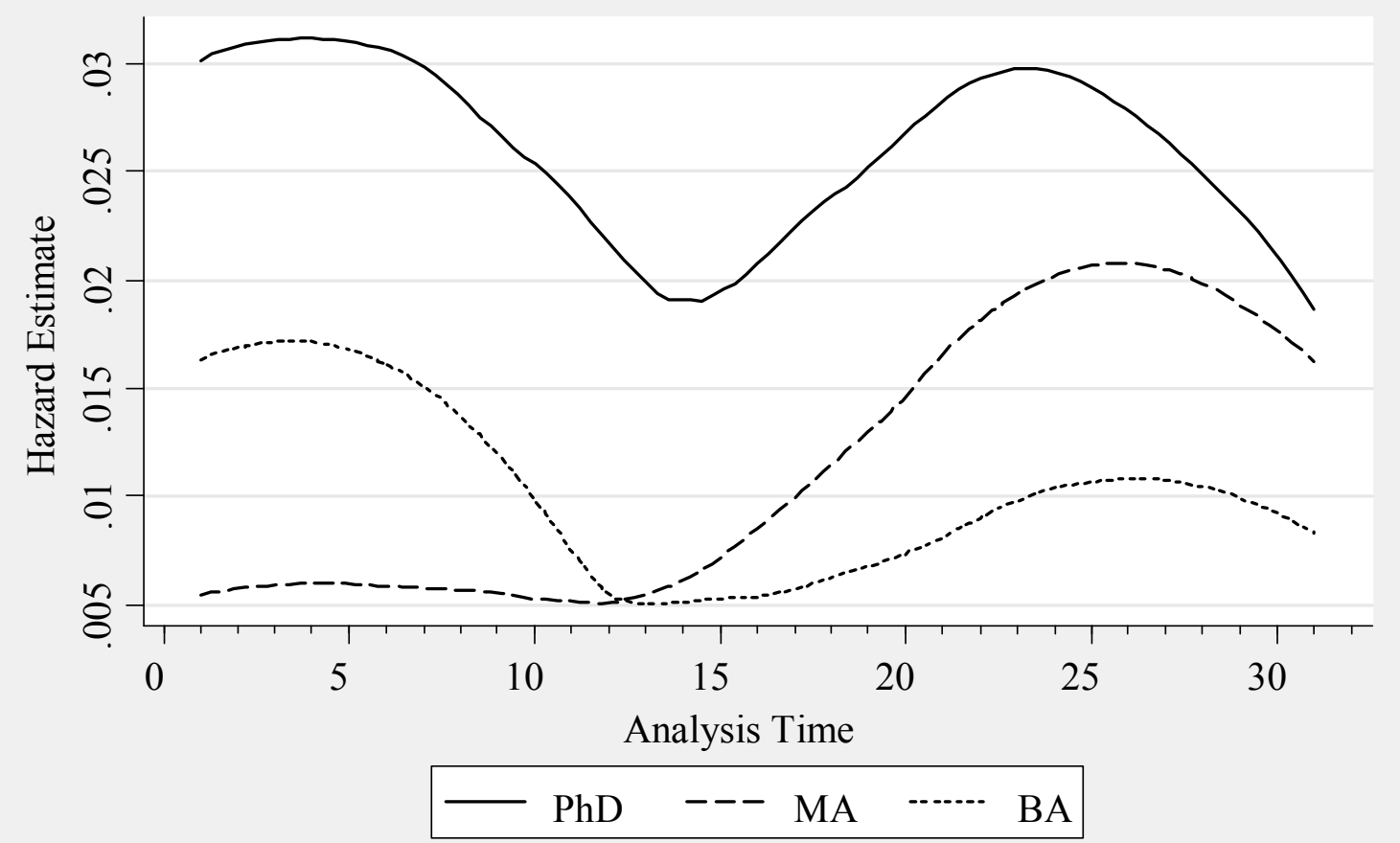

Source: Authors' calculations using CAPP and ASC data. 
Figure 3. Smoothed Hazard Estimates by SAT Group

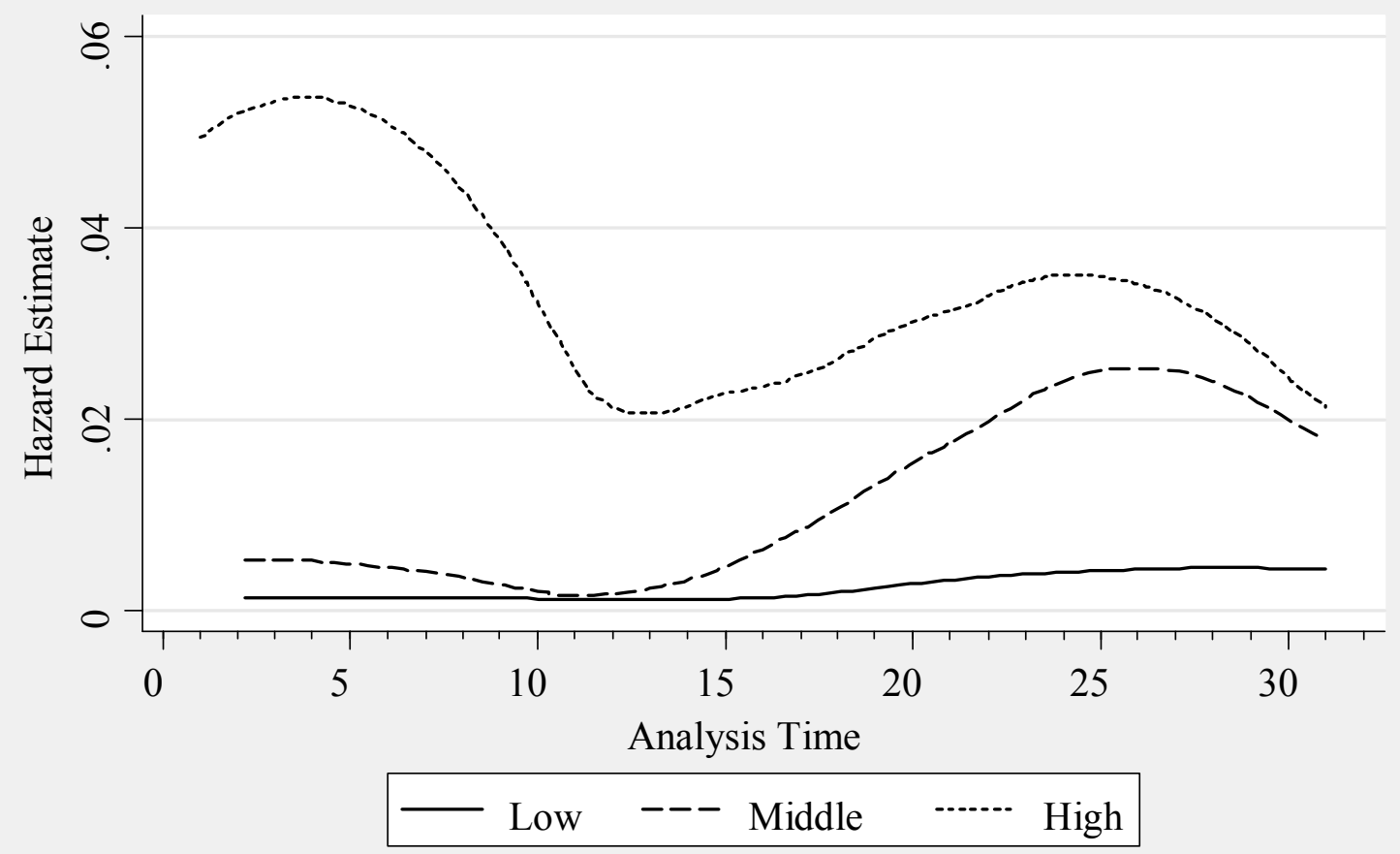

Source: Authors' calculations using CAPP and ASC data. 
Table 2. Proportional Hazards Model, Coefficient Estimates

\begin{tabular}{|c|c|c|c|c|c|c|c|c|}
\hline & (1) & (2) & (3) & (4) & (5) & (6) & (7) & (8) \\
\hline & & & \multicolumn{3}{|c|}{ Carnegie Classification } & \multicolumn{3}{|c|}{ SAT Group } \\
\hline & All & All & $\mathrm{PhD}$ & MA & $\mathrm{BA}$ & Low & Middle & High \\
\hline memberfee & $\begin{array}{l}-0.286^{* * *} \\
(0.050)\end{array}$ & $\begin{array}{c}-0.193 * * * \\
(0.048)\end{array}$ & $\begin{array}{c}-0.113 \\
(0.201)\end{array}$ & $\begin{array}{l}-0.211^{* *} \\
(0.105)\end{array}$ & $\begin{array}{l}-0.197 * * * \\
(0.058)\end{array}$ & $\begin{array}{c}-0.340^{* *} \\
(0.162)\end{array}$ & $\begin{array}{c}-0.183 * \\
(0.095)\end{array}$ & $\begin{array}{c}-0.110^{* *} \\
(0.054)\end{array}$ \\
\hline pctcapp & $\begin{array}{l}0.022 * * * \\
(0.004)\end{array}$ & $\begin{array}{c}0.008 * \\
(0.005)\end{array}$ & $\begin{array}{c}0.011 \\
(0.013)\end{array}$ & $\begin{array}{l}0.015 * * \\
(0.007)\end{array}$ & $\begin{array}{c}0.000 \\
(0.007)\end{array}$ & $\begin{array}{c}-0.011 \\
(0.014)\end{array}$ & $\begin{array}{l}0.019 * * \\
(0.008)\end{array}$ & $\begin{array}{c}0.002 \\
(0.007)\end{array}$ \\
\hline sat & & $\begin{array}{l}5.382 * * * \\
(0.927)\end{array}$ & $\begin{array}{l}5.655^{* *} \\
(2.440)\end{array}$ & $\begin{array}{c}1.377 \\
(3.051)\end{array}$ & $\begin{array}{l}4.473 * * * \\
(1.285)\end{array}$ & $\begin{array}{c}14.000 \\
(17.791)\end{array}$ & $\begin{array}{l}-52.569 * * \\
(23.543)\end{array}$ & $\begin{array}{l}8.438^{* * * *} \\
(3.232)\end{array}$ \\
\hline satsq & & $\begin{array}{l}-0.204 * * * \\
(0.039)\end{array}$ & $\begin{array}{c}-0.223^{* *} \\
(0.100)\end{array}$ & $\begin{array}{c}-0.025 \\
(0.144)\end{array}$ & $\begin{array}{l}-0.159 * * * \\
(0.054)\end{array}$ & $\begin{array}{c}-0.654 \\
(0.942)\end{array}$ & $\begin{array}{l}2.489 * * \\
(1.088)\end{array}$ & $\begin{array}{c}-0.329 * * * \\
(0.126)\end{array}$ \\
\hline pctcampus & & $\begin{array}{l}0.009 * * \\
(0.004)\end{array}$ & $\begin{array}{c}-0.006 \\
(0.009)\end{array}$ & $\begin{array}{c}0.009 \\
(0.007)\end{array}$ & $\begin{array}{l}0.020 * * * \\
(0.008)\end{array}$ & $\begin{array}{c}0.009 \\
(0.013)\end{array}$ & $\begin{array}{c}0.005 \\
(0.006)\end{array}$ & $\begin{array}{l}0.014 * * \\
(0.006)\end{array}$ \\
\hline religion & & $\begin{array}{c}-0.578 * * * \\
(0.151)\end{array}$ & $\begin{array}{c}-0.367 \\
(0.386)\end{array}$ & $\begin{array}{c}-0.227 \\
(0.267)\end{array}$ & $\begin{array}{l}-0.789 * * * \\
(0.222)\end{array}$ & $\begin{array}{c}-1.209 * * \\
(0.557)\end{array}$ & $\begin{array}{c}-0.525^{* *} \\
(0.263)\end{array}$ & $\begin{array}{l}-0.602 * * * \\
(0.221)\end{array}$ \\
\hline $\begin{array}{l}\text { log likelihood } \\
\mathrm{N}\end{array}$ & $\begin{array}{c}-1266.196 \\
15471\end{array}$ & $\begin{array}{c}-1145.809 \\
15471\end{array}$ & $\begin{array}{c}-165.870 \\
1148\end{array}$ & $\begin{array}{c}-324.078 \\
5856\end{array}$ & $\begin{array}{c}-637.790 \\
8467\end{array}$ & $\begin{array}{c}-83.448 \\
6715\end{array}$ & $\begin{array}{c}-298.372 \\
5966\end{array}$ & $\begin{array}{c}-557.032 \\
2790\end{array}$ \\
\hline
\end{tabular}

Notes: $* \mathrm{p}<.10, * * \mathrm{p}<.05, * * * \mathrm{p}<.01$. Standard errors in parentheses. Models $2-8$ include percent in-state students, urban location, and rural location as additional independent variables. Models 1, 2, 6, 7, and 8 are stratified by Carnegie classification. Networks are at the state level. All independent variables except membership fee and network size are fixed at 1974 values. 
Table 3. OLS Membership Effects on Log Admissions Outcomes

\begin{tabular}{|c|c|c|c|c|c|c|c|c|}
\hline & (1) & $(2)$ & (3) & (4) & $(5)$ & (6) & $(7)$ & $(8)$ \\
\hline & apply & admit & enroll & acceptrate & yieldrate & sat & petsoc & pctpell \\
\hline L.log_applyfee & $\begin{array}{l}-0.062 * * * \\
(0.015)\end{array}$ & $\begin{array}{l}-0.073 * * * \\
(0.015)\end{array}$ & $\begin{array}{l}-0.041 * * * \\
(0.013)\end{array}$ & $\begin{array}{l}-0.011 \\
(0.009)\end{array}$ & $\begin{array}{l}0.042 * * * \\
(0.011)\end{array}$ & $\begin{array}{l}0.015 * * * \\
(0.004)\end{array}$ & $\begin{array}{l}0.085 * * * \\
(0.025)\end{array}$ & $\begin{array}{l}-0.011 \\
(0.013)\end{array}$ \\
\hline L.log_tuition & $\begin{array}{c}0.004 \\
(0.042)\end{array}$ & $\begin{array}{l}0.180 * * * \\
(0.046)\end{array}$ & $\begin{array}{l}-0.065^{*} \\
(0.037)\end{array}$ & $\begin{array}{l}0.176^{* * * *} \\
(0.029)\end{array}$ & $\begin{array}{l}-0.220 * * * \\
(0.035)\end{array}$ & $\begin{array}{l}-0.000 \\
(0.007)\end{array}$ & $\begin{array}{l}0.158 * * * \\
(0.060)\end{array}$ & $\begin{array}{c}0.037 \\
(0.031)\end{array}$ \\
\hline L.capp & $\begin{array}{l}0.057 * * * \\
(0.012)\end{array}$ & $\begin{array}{l}0.052 * * * \\
(0.010)\end{array}$ & $\begin{array}{l}0.037 * * * \\
(0.008)\end{array}$ & $\begin{array}{l}-0.004 \\
(0.007)\end{array}$ & $\begin{array}{l}-0.028 * * * \\
(0.008)\end{array}$ & $\begin{array}{l}-0.011 * * * \\
(0.002)\end{array}$ & $\begin{array}{l}0.154 * * * \\
(0.022)\end{array}$ & $\begin{array}{l}0.024 * * \\
(0.012)\end{array}$ \\
\hline L.pctcapp_st & $\begin{array}{l}-0.000 \\
(0.000)\end{array}$ & $\begin{array}{l}-0.001 \\
(0.000)\end{array}$ & $\begin{array}{l}0.001 * * * \\
(0.000)\end{array}$ & $\begin{array}{l}-0.000 \\
(0.000)\end{array}$ & $\begin{array}{l}0.001 * * * \\
(0.000)\end{array}$ & $\begin{array}{l}-0.001 * * * \\
(0.000)\end{array}$ & $\begin{array}{l}0.003 * * * \\
(0.001)\end{array}$ & $\begin{array}{l}0.001 * * * \\
(0.000)\end{array}$ \\
\hline L.sat & $\begin{array}{c}0.002 \\
(0.053)\end{array}$ & $\begin{array}{l}0.373 * * * \\
(0.060)\end{array}$ & $\begin{array}{c}0.053 \\
(0.042)\end{array}$ & $\begin{array}{l}0.374 * * * \\
(0.042)\end{array}$ & $\begin{array}{l}-0.292 * * * \\
(0.047)\end{array}$ & & $\begin{array}{l}-0.135^{*} \\
(0.080)\end{array}$ & $\begin{array}{l}0.138 * * \\
(0.054)\end{array}$ \\
\hline L.satsq & $\begin{array}{c}0.001 \\
(0.002)\end{array}$ & $\begin{array}{l}-0.018 * * * \\
(0.003)\end{array}$ & $\begin{array}{l}-0.003 \\
(0.002)\end{array}$ & $\begin{array}{l}-0.019 * * * \\
(0.002)\end{array}$ & $\begin{array}{l}0.014 * * * \\
(0.002)\end{array}$ & & $\begin{array}{c}0.004 \\
(0.004)\end{array}$ & $\begin{array}{l}-0.011 * * * \\
(0.003)\end{array}$ \\
\hline L.pctcampus & $\begin{array}{l}0.003 * * * \\
(0.000)\end{array}$ & $\begin{array}{l}0.002 * * * \\
(0.000)\end{array}$ & $\begin{array}{l}0.001 * * * \\
(0.000)\end{array}$ & $\begin{array}{l}-0.000 \\
(0.000)\end{array}$ & $\begin{array}{l}-0.001 * * * \\
(0.000)\end{array}$ & $\begin{array}{l}0.000 * * * \\
(0.000)\end{array}$ & $\begin{array}{l}-0.004 * * * \\
(0.001)\end{array}$ & $\begin{array}{c}0.000 \\
(0.000)\end{array}$ \\
\hline L.religion & $\begin{array}{c}0.002 \\
(0.027)\end{array}$ & $\begin{array}{l}-0.012 \\
(0.025)\end{array}$ & $\begin{array}{l}-0.009 \\
(0.024)\end{array}$ & $\begin{array}{l}-0.016 \\
(0.013)\end{array}$ & $\begin{array}{c}0.007 \\
(0.017)\end{array}$ & $\begin{array}{l}-0.012 * * * \\
(0.005)\end{array}$ & $\begin{array}{l}-0.063 \\
(0.074)\end{array}$ & $\begin{array}{l}0.074 * * \\
(0.032)\end{array}$ \\
\hline $\begin{array}{l}\text { R-squared } \\
\mathrm{N}\end{array}$ & $\begin{array}{r}0.455 \\
10972\end{array}$ & $\begin{array}{r}0.385 \\
10960\end{array}$ & $\begin{array}{r}0.085 \\
12791\end{array}$ & $\begin{array}{r}0.142 \\
10941\end{array}$ & $\begin{array}{c}0.287 \\
10896\end{array}$ & $\begin{array}{r}0.124 \\
11014\end{array}$ & $\begin{array}{c}0.381 \\
10826\end{array}$ & $\begin{array}{r}0.200 \\
10702\end{array}$ \\
\hline
\end{tabular}

Notes: $* \mathrm{p}<.10, * * \mathrm{p}<.05, * * * \mathrm{p}<.01$. Robust standard errors in parentheses. Models include one-year lagged dummy variable for no application fee, percent in-state students, urban location, rural location, and Carnegie classification dummy variables as additional independent variables and institution, state, and year fixed-effects. Networks are at the state level. 
Table 4. OLS Membership Effects on Log Admissions Outcomes, Interaction Terms

\begin{tabular}{|c|c|c|c|c|c|c|c|c|}
\hline & (1) & (2) & (3) & (4) & (5) & (6) & (7) & (8) \\
\hline & apply & admit & enroll & acceptrate & yieldrate & sat & petsoc & pctpell \\
\hline L.capp & $\begin{array}{c}0.030 * \\
(0.016)\end{array}$ & $\begin{array}{l}0.055^{* * *} \\
(0.014)\end{array}$ & $\begin{array}{l}0.032 * * * \\
(0.012)\end{array}$ & $\begin{array}{l}0.023^{* *} \\
(0.011)\end{array}$ & $\begin{array}{l}-0.026^{* *} \\
(0.011)\end{array}$ & $\begin{array}{l}-0.014 * * * \\
(0.003)\end{array}$ & $\begin{array}{l}0.239 * * * \\
(0.031)\end{array}$ & $\begin{array}{c}0.037 * \\
(0.020)\end{array}$ \\
\hline L.pctcapp & $\begin{array}{l}-0.001 \\
(0.001)\end{array}$ & $\begin{array}{l}-0.000 \\
(0.000)\end{array}$ & $\begin{array}{l}0.001 * * \\
(0.000)\end{array}$ & $\begin{array}{c}0.000 \\
(0.000)\end{array}$ & $\begin{array}{l}0.001^{* * *} \\
(0.000)\end{array}$ & $\begin{array}{l}-0.001 * * * \\
(0.000)\end{array}$ & $\begin{array}{l}0.004 * * * \\
(0.001)\end{array}$ & $\begin{array}{l}0.002 * * * \\
(0.000)\end{array}$ \\
\hline L.capp * L.pctcapp & $\begin{array}{l}0.001^{* *} \\
(0.000)\end{array}$ & $\begin{array}{l}-0.000 \\
(0.000)\end{array}$ & $\begin{array}{c}0.000 \\
(0.000)\end{array}$ & $\begin{array}{l}-0.001 * * * \\
(0.000)\end{array}$ & $\begin{array}{l}-0.000 \\
(0.000)\end{array}$ & $\begin{array}{c}0.000 \\
(0.000)\end{array}$ & $\begin{array}{l}-0.003 * * * \\
(0.001)\end{array}$ & $\begin{array}{l}-0.000 \\
(0.001)\end{array}$ \\
\hline & apply & admit & enroll & acceptrate & yieldrate & sat & petsoc & pctpell \\
\hline L.capp & $\begin{array}{l}0.243 * * \\
(0.101)\end{array}$ & $\begin{array}{l}1.081^{* * *} \\
(0.089)\end{array}$ & $\begin{array}{l}0.417 * * * \\
(0.072)\end{array}$ & $\begin{array}{l}0.845^{* * *} \\
(0.065)\end{array}$ & $\begin{array}{l}-0.674 * * * \\
(0.062)\end{array}$ & & $\begin{array}{c}0.283 \\
(0.177)\end{array}$ & $\begin{array}{l}0.534 * * * \\
(0.105)\end{array}$ \\
\hline L.sat & $\begin{array}{l}0.027 * * * \\
(0.006)\end{array}$ & $\begin{array}{c}0.007 \\
(0.006)\end{array}$ & $\begin{array}{c}0.004 \\
(0.005)\end{array}$ & $\begin{array}{l}-0.019 * * * \\
(0.004)\end{array}$ & $\begin{array}{c}-0.004 \\
(0.005)\end{array}$ & & $\begin{array}{l}-0.055^{* * * *} \\
(0.010)\end{array}$ & $\begin{array}{c}-0.080 * * * \\
(0.006)\end{array}$ \\
\hline L.capp * L.sat & $\begin{array}{c}-0.016^{*} \\
(0.008)\end{array}$ & $\begin{array}{l}-0.089 * * * \\
(0.007)\end{array}$ & $\begin{array}{l}-0.033 * * * \\
(0.006)\end{array}$ & $\begin{array}{c}-0.073 * * * \\
(0.006)\end{array}$ & $\begin{array}{l}0.056^{* * * *} \\
(0.005)\end{array}$ & & $\begin{array}{c}-0.011 \\
(0.015)\end{array}$ & $\begin{array}{l}-0.045^{* * *} \\
(0.009)\end{array}$ \\
\hline
\end{tabular}

Notes: $* \mathrm{p}<.10,{ }^{* *} \mathrm{p}<.05,{ }^{* * *} \mathrm{p}<.01$. Robust standard errors in parentheses. Models include one-year lagged dummy variable for no application fee, SAT and SAT squared, percent on-campus students, percent in-state students, religious affiliation, urban location, rural location, and Carnegie classification dummy variables as additional independent variables and institution, state, and year fixed-effects. Networks are at the state level. 
Table 5. 2SLS Membership Effects on Log Admissions Outcomes

\begin{tabular}{|c|c|c|c|c|c|c|c|c|}
\hline & (1) & $(2)$ & (3) & (4) & $(5)$ & (6) & $(7)$ & $(8)$ \\
\hline & apply & admit & enroll & acceptrate & yieldrate & sat & pctsoc & pctpell \\
\hline L.log_applyfee & $\begin{array}{l}-0.062 * * * \\
(0.015)\end{array}$ & $\begin{array}{l}-0.073 * * * \\
(0.015)\end{array}$ & $\begin{array}{l}-0.041 * * * \\
(0.013)\end{array}$ & $\begin{array}{l}-0.011 \\
(0.009)\end{array}$ & $\begin{array}{l}0.043 * * * \\
(0.011)\end{array}$ & $\begin{array}{l}0.015 * * * \\
(0.004)\end{array}$ & $\begin{array}{l}0.085 * * * \\
(0.025)\end{array}$ & $\begin{array}{l}-0.011 \\
(0.013)\end{array}$ \\
\hline L.log_tuition & $\begin{array}{c}0.004 \\
(0.042)\end{array}$ & $\begin{array}{l}0.180 * * * \\
(0.046)\end{array}$ & $\begin{array}{l}-0.065^{*} \\
(0.037)\end{array}$ & $\begin{array}{l}0.176^{* * * *} \\
(0.029)\end{array}$ & $\begin{array}{l}-0.219 * * * \\
(0.035)\end{array}$ & $\begin{array}{l}-0.000 \\
(0.007)\end{array}$ & $\begin{array}{l}0.158 * * * \\
(0.060)\end{array}$ & $\begin{array}{c}0.038 \\
(0.031)\end{array}$ \\
\hline L.capp & $\begin{array}{l}0.060 * * * \\
(0.013)\end{array}$ & $\begin{array}{l}0.057 * * * \\
(0.012)\end{array}$ & $\begin{array}{l}0.035 * * * \\
(0.010)\end{array}$ & $\begin{array}{c}0.000 \\
(0.009)\end{array}$ & $\begin{array}{l}-0.037 * * * \\
(0.009)\end{array}$ & $\begin{array}{l}-0.012 * * * \\
(0.002)\end{array}$ & $\begin{array}{l}0.155 * * * \\
(0.024)\end{array}$ & $\begin{array}{c}0.012 \\
(0.014)\end{array}$ \\
\hline L.pctcapp & $\begin{array}{l}-0.000 \\
(0.000)\end{array}$ & $\begin{array}{l}-0.001 \\
(0.000)\end{array}$ & $\begin{array}{l}0.001 * * * \\
(0.000)\end{array}$ & $\begin{array}{l}-0.000 \\
(0.000)\end{array}$ & $\begin{array}{l}0.001 * * * \\
(0.000)\end{array}$ & $\begin{array}{l}-0.001 * * * \\
(0.000)\end{array}$ & $\begin{array}{l}0.003 * * * \\
(0.001)\end{array}$ & $\begin{array}{l}0.001 * * * \\
(0.000)\end{array}$ \\
\hline L.sat & $\begin{array}{c}0.002 \\
(0.053)\end{array}$ & $\begin{array}{l}0.374 * * * \\
(0.060)\end{array}$ & $\begin{array}{c}0.052 \\
(0.042)\end{array}$ & $\begin{array}{l}0.375 * * * \\
(0.042)\end{array}$ & $\begin{array}{l}-0.294 * * * \\
(0.046)\end{array}$ & & $\begin{array}{l}-0.135^{*} \\
(0.080)\end{array}$ & $\begin{array}{l}0.136^{* *} \\
(0.054)\end{array}$ \\
\hline L.satsq & $\begin{array}{c}0.001 \\
(0.002)\end{array}$ & $\begin{array}{l}-0.018 * * * \\
(0.003)\end{array}$ & $\begin{array}{l}-0.003 \\
(0.002)\end{array}$ & $\begin{array}{l}-0.019 * * * \\
(0.002)\end{array}$ & $\begin{array}{l}0.014 * * * \\
(0.002)\end{array}$ & & $\begin{array}{c}0.004 \\
(0.004)\end{array}$ & $\begin{array}{l}-0.011 * * * \\
(0.003)\end{array}$ \\
\hline L.pctcampus & $\begin{array}{l}0.003 * * * \\
(0.000)\end{array}$ & $\begin{array}{l}0.002 * * * \\
(0.000)\end{array}$ & $\begin{array}{l}0.001 * * * \\
(0.000)\end{array}$ & $\begin{array}{l}-0.000 \\
(0.000)\end{array}$ & $\begin{array}{l}-0.001 * * * \\
(0.000)\end{array}$ & $\begin{array}{l}0.000 * * * \\
(0.000)\end{array}$ & $\begin{array}{l}-0.004 * * * \\
(0.001)\end{array}$ & $\begin{array}{c}0.000 \\
(0.000)\end{array}$ \\
\hline L.religion & $\begin{array}{c}0.002 \\
(0.027)\end{array}$ & $\begin{array}{l}-0.012 \\
(0.025)\end{array}$ & $\begin{array}{l}-0.009 \\
(0.024)\end{array}$ & $\begin{array}{l}-0.016 \\
(0.013)\end{array}$ & $\begin{array}{c}0.007 \\
(0.017)\end{array}$ & $\begin{array}{l}-0.012 * * * \\
(0.005)\end{array}$ & $\begin{array}{l}-0.063 \\
(0.074)\end{array}$ & $\begin{array}{l}0.073 * * \\
(0.032)\end{array}$ \\
\hline R-squared & 0.455 & 0.385 & 0.085 & 0.142 & 0.287 & 0.124 & 0.381 & 0.200 \\
\hline $\mathrm{N}$ & 10972 & 10960 & 12791 & 10941 & 10896 & 11003 & 10826 & 10702 \\
\hline First stage F-stat & 6100 & 6212 & 7303 & 6189 & 6153 & 5795 & 6262 & 5680 \\
\hline Hansen-Sargan $p$ & 0.821 & 0.901 & 0.245 & 0.959 & 0.382 & 0.573 & 0.976 & 0.272 \\
\hline
\end{tabular}

Notes: $* \mathrm{p}<.10, * * \mathrm{p}<.05, * * * \mathrm{p}<.01$. Robust standard errors in parentheses. Models include one-year lagged dummy variable for no application fee, percent in-state students, urban location, rural location, and Carnegie classification dummy variables as additional independent variables and institution, state, and year fixed-effects. Networks are at the state level. Instruments for one-year lagged membership are two-year and three-year lagged membership and members share in the state. 
Table 6. First Difference Falsification Tests

\begin{tabular}{|c|c|c|c|c|c|c|c|c|}
\hline & (1) & (2) & (3) & (4) & (5) & (6) & (7) & (8) \\
\hline & apply & admit & enroll & acceptrate & yieldrate & sat & pctsoc & pctpell \\
\hline L3D.capp & $\begin{array}{c}0.025 \\
(0.017)\end{array}$ & $\begin{array}{c}-0.001 \\
(0.018)\end{array}$ & $\begin{array}{c}0.007 \\
(0.021)\end{array}$ & $\begin{array}{c}-0.026^{* *} \\
(0.012)\end{array}$ & $\begin{array}{c}-0.002 \\
(0.019)\end{array}$ & $\begin{array}{c}0.000 \\
(0.003)\end{array}$ & $\begin{array}{c}0.021 \\
(0.039)\end{array}$ & $\begin{array}{c}-0.022 \\
(0.018)\end{array}$ \\
\hline L2D.capp & $\begin{array}{c}0.026 \\
(0.017)\end{array}$ & $\begin{array}{c}0.029 \\
(0.018)\end{array}$ & $\begin{array}{c}0.002 \\
(0.020)\end{array}$ & $\begin{array}{c}0.002 \\
(0.012)\end{array}$ & $\begin{array}{c}-0.022 \\
(0.019)\end{array}$ & $\begin{array}{c}0.002 \\
(0.003)\end{array}$ & $\begin{array}{c}0.014 \\
(0.039)\end{array}$ & $\begin{array}{c}0.003 \\
(0.018)\end{array}$ \\
\hline LD.capp & $\begin{array}{l}0.070^{* * *} \\
(0.016)\end{array}$ & $\begin{array}{l}0.043 * * \\
(0.017)\end{array}$ & $\begin{array}{c}0.010 \\
(0.020)\end{array}$ & $\begin{array}{c}-0.029 * * \\
(0.012)\end{array}$ & $\begin{array}{c}-0.039 * * \\
(0.018)\end{array}$ & $\begin{array}{c}-0.001 \\
(0.003)\end{array}$ & $\begin{array}{c}0.041 \\
(0.038)\end{array}$ & $\begin{array}{c}0.019 \\
(0.016)\end{array}$ \\
\hline D.capp & $\begin{array}{c}-0.007 \\
(0.015)\end{array}$ & $\begin{array}{c}-0.005 \\
(0.016)\end{array}$ & $\begin{array}{c}-0.002 \\
(0.019)\end{array}$ & $\begin{array}{c}0.002 \\
(0.011)\end{array}$ & $\begin{array}{c}0.001 \\
(0.017)\end{array}$ & $\begin{array}{c}0.002 \\
(0.003)\end{array}$ & $\begin{array}{r}0.066^{*} \\
(0.037)\end{array}$ & $\begin{array}{c}-0.005 \\
(0.016)\end{array}$ \\
\hline FD.capp & $\begin{array}{c}0.004 \\
(0.015)\end{array}$ & $\begin{array}{c}0.010 \\
(0.016)\end{array}$ & $\begin{array}{c}0.005 \\
(0.019)\end{array}$ & $\begin{array}{c}0.007 \\
(0.011)\end{array}$ & $\begin{array}{c}-0.005 \\
(0.018)\end{array}$ & $\begin{array}{c}-0.001 \\
(0.003)\end{array}$ & $\begin{array}{c}0.020 \\
(0.037)\end{array}$ & $\begin{array}{c}0.004 \\
(0.017)\end{array}$ \\
\hline
\end{tabular}

Notes: $* \mathrm{p}<.10, * * \mathrm{p}<.05, * * * \mathrm{p}<.01$. Standard errors in parentheses. Models include one-year lagged first difference of application fee, dummy variable for no application fee, log tuition, percent member, SAT and SAT squared, percent oncampus students, percent in-state students, religious affiliation, urban location, rural location, and Carnegie classification dummy variables as additional independent variables and year fixed-effects. Networks are at the state level. 


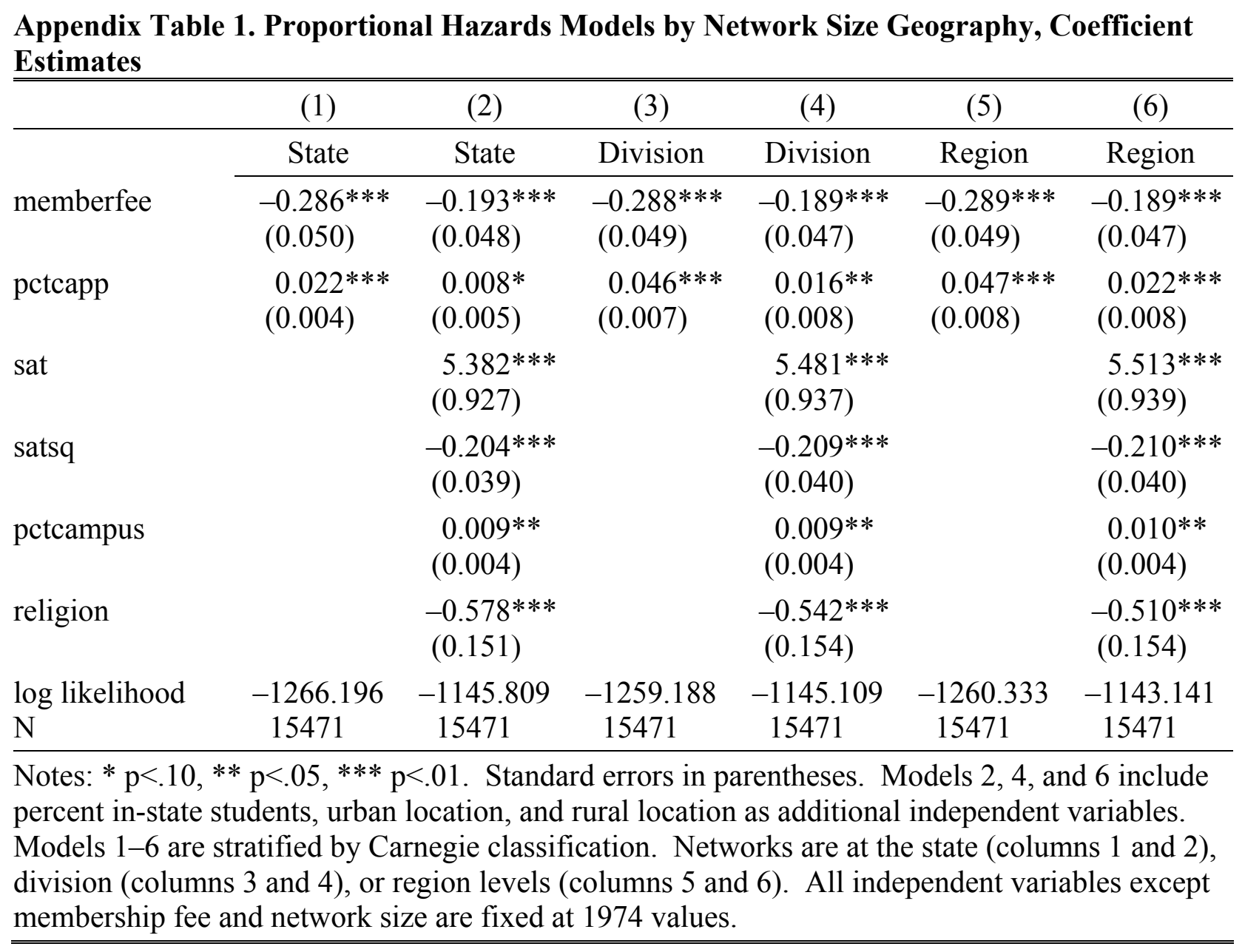

